\title{
Clinical Characteristics of Patients with Bronchopulmo- nary Dysplasia Admitted to Pediatric Intensive Care Unit
}

Yeon Chul Choi, M.D., Won Kyoung Jhang, M.D., and Seong Jong Park, M.D.

Department of Pediatrics, Asan Medical Center Children's Hospital, University of Ulsan College of Medicine, Seoul, Korea

\section{ABSTRACT}

Purpose: As the incidence of bronchopulmonary dysplasia (BPD) has increased, it is important to understand the clinical outcomes of BPD patients discharged from neonatal intensive care units (NICU). The purpose of our study was to describe the characteristics of BPD patients who are re-hospitalized in a pediatric intensive care unit (PICU) and to evaluate the prognostic outcome factors.

Methods: We retrospectively reviewed the medical records of BPD patients who were admitted to our PICU between May 2006 and November 2014. In total, we identified 101 cases which were divided into two groups, group 1, those who required intensive care for an acute illness or disease aggravation $(n=62)$, and group 2 , those who were admitted for post-operative care unrelated to having BPD as a control group $(\mathrm{n}=39)$. We subsequently compared the characteristics.

Results: Most patients in group 1 were aged less than 1 year, with weight below the 3rd percentile for age at the time of their PICU admission. The main cause for their admission was respiratory failure, requiring mechanical ventilation. When comparing the two groups, group 1 showed higher gestational age at birth, and a longer duration of mechanical ventilation, oxygen support, and NICU hospitalization than group 2. However, we failed to identify any factor significantly associated with the duration of the PICU stay, hospital stay, and mortality. Further large-scale, long-term follow-up studies will be necessary.

Conclusion: As the majority of patients are admitted to PICU because of respiratory symptoms during their infantile period, careful follow-up with supportive care and prevention of respiratory infection are required.

Key Words: BPD, Chronic lung disease of infancy, PICU, Long-term outcome

서론

신생아 중환자 관리가 향상됨에 따라 최근 극소저체중출생아(very low birth weight infant)와 초극소저체중출생아(extremely low birth weight infant)의 생존율은 꾸준히 향상되고 있다. 산전 스테로이드 투여와 surfactant 투여와 같은 신생아 호흡곤란 증후군 (respiratory distress syndrome of newborn)의 예방 및 치료의 발전에도 불구하고 기관지
Received: 18 October 2015

Revised: 17 April 2016

Accepted: 21 April 2016

Correspondence to: Seong Jong Park

Department of Pediatrics, Asan

Medical Center Children's Hospital, University of Ulsan College of

Medicine, 88 Olympic-ro 43 gil,

Songpa-gu, Seoul 05505, Korea

Tel: +82-2-3010-3386

Fax: +82-2-473-3725

E-mail: drpsj@amc.seoul.kr

Copyright(c)

By Korean Society of Neonatology.

All right reserved.

This is an Open-Access article distributed under the terms of the Creative Commons Attribution Non-Commercial License (http://creativecommons.org/licenses/ by-nc/4.0), which permits unrestricted non-commercial use, distribution, and reproduction in any medium, provided the original work is properly cited. 
폐이형성증(bronchopulmonary dysplasia, BPD)은 기계환기가 적용된 미숙아에서의 주요한 합병증으로 남아 있으며 ${ }^{1)}$, 이는 영아 기의 만성폐질환(chronic lung disease, CLD)의 가장 흔한 원인 으로 자리매김 하였다.

신생아중환자실에서의 기관지폐이형성증에 대한 연구는 활발 히 진행되고 있지만, 이의 자연경과와 장기적인 예후에 대한 연구 는 부족한 가운데, 1990년 Northway 등은 영아기에 기관지폐이 형성증을 않은 대부분의 환자에게서 어린이 및 청소년기에 폐기 능 장애가 동반됨을 발표하였달. 국내에서 이들 환자들의 예후 및 장기적인 추적 관찰 결과에 대한 연구는 드문 실정으로 이에 본 연구에서는 기관지폐이형성증을 가진 환자들 중 소아중환자실 입원이 필요하였던 환자들을 중심으로 임상 양상, 예후에 영향을 미치는 관련 인자에 대해 분석 및 추적 관찰 결과를 알아보고자 하였다.

\section{대상 및 방법}

\section{1. 대상}

2006년 5월부터 2014년 11월까지 서울아산병원 소아중환자실 에 입원하여 치료받은 환자 중 본원 또는 타원의 신생아 중환자실 에서 미숙아 및 선천기형으로 치료 받은 뒤 기관지폐이형성증으 로 추적관찰 중인 환자를 대상으로 하였다. 본 연구는 서울아산 병원 임상연구심의위원회(institution review board, IRB 20151284)의 심의를 통과하였으며 후향적 의무 고찰 연구로 동의서 획 득은 면제되었다.

\section{2. 방법}

환자들의 전자의무기록을 중심으로 후향적으로 자료를 수집, 검토하였다. 신생아 중환자실 입원과 관련하여 재태 연령, 출생 체중, Apgar score, 산모의 나이, 분만 방법, 산전 스테로이드 투 여 여부, 신생아 호흡곤란 증후군에 따른 surfactant 투여 여부, 입원 기간, 인공호흡기 치료 여부, 인공호흡기 치료 기간, 산소 투 여 기간, 기관지폐이형성증의 중증도, 귀가 시 산소 필요 유무 등 을 확인 하였다. 기관지폐이형성증의 진단과 중증도 분류는 Jobe 와 Bancalari 등에 의해 제시된 진단기준 ${ }^{3}$ 을 사용하였다. 이후 임 상 경과에 대하여, 신생아중환자실 퇴실 후 소아중환자실 입실까 지의 기간, 소아중환자실 입원 횟수, 소아중환자실 입원 당시의 나 이, 체중, 신장, 소아중환자실 입원 이유, 소아중환자실 입원기간 중 인공호흡기 사용 유무, 인공호흡기 보조 정도, 사용 약물, 소아 중환자실 재실 기간, 일반 병실 재실 기간을 포함한 총 입원 기간, 사망 했을 경우 사망 원인, 퇴원 이후 추적관찰 결과 등의 자료를 수집하였다.
한 환자가 소아중환자실에 여러 번 입원을 하였던 경우라도 다 른 시기에 다른 원인으로 입원 치료가 필요하였고, 다른 임상 경 과를 보였던 바, 소아중환자실 입원 관련 지표에 대하여 각각의 개 별 증례로 분석하였다. 대상 환자들은 소아중환자실 입원 목적에 따른 급성 질환 악화로 중환자실 집중 치료가 필요하였던 군(1군, Group 1)과 폐질환 이외의 원인으로 수술적 치료 후 수술 후 관 리를 위해 중환자실에 입원한 군(2군, Group 2)으로 나누어 두 군 간의 비교 분석을 시행하였다. 결과 변수로 소아중환자실 재실 기 간 및 총 재원 기간, 사망에 대한 예후 인자를 분석하였다.

\section{3. 통계 처리 방법}

통계 분석은 SPSS version 18.0 (SPSS Inc., Chicago, IL, USA) 을 사용하였다. 연속형 변수에 대하여는 평균표준편차로 나타 내었고 명목형 변수에 대하여는 해당 환자 수 및 \%로 표시하였다. 두군 간의 비교 분석은, 정규 분포를 만족하는 연속형 변수에 대 하여는 독립표본 $t$-검정을 시행하였고 명목형 변수에 대하여는 카 이제곱 검정을 시행하였다. 정규분포를 만족하지 않는 연속형 변 수에 대하여는 Mann-Whitney $U$ 검정법을, 명목형 변수에 대하 여는 wilcoxon 부호-서열 검증법을 이용하여 분석을 시행하였다. 소아중환자실 입원 후 재실 기간 및 사망에 대해 영향을 미치는 요소를 알아보고자 단변수 분석 및 다중 로지스틱 회귀분석을 시 행하였으며 모든 분석 결과에 대해 $P$ 값이 0.05 미만인 경우를 통 계적으로 유의한 것으로 판단하였다.

\section{결과}

\section{1. 대상 환자들의 임상적 특징 및 비교 분석}

연구 기간 동안 소아중환자실에 방문한 기관지폐이형성증을 가 진 환자들은 총 78 명으로 총 101례의 소아중환자실 입원이 있었 다. 한 환자가 소아중환자실에 여러 번 입원을 하였던 경우라도 다 른 시기에 다른 원인으로 입원 치료가 필요하였고, 다른 임상 경 과를 보였다. 이에 소아중환자실 입원 관련 지표에 대하여 각각의 개별 증례로 분석한 결과, 이들 중 1 군에 속하는 41 명의 환자에서 급성 질환 악화에 따른 소아중환자실 입원이 62례가 있었고, 2 회 이상 소아중환자실 입원 치료가 필요하였던 환자는 10 명(24.4\%) 였다(Table 1). 2 군에 속하는 37명의 환자들의 경우 미숙아망막 증, 서혜부 탈장 등의 수술 후 관리를 위해 39례의 소아중환자실 입원이 있었고, 2 명의 환자가 2 회 소아중환자실에 입원하였다.

전체 환자 중 남아는 45명(57.7\%), 여아는 33명(42.3\%)이었고, 소아중환자실 입원 당시 평균 나이, 체중과 신장은 각각 $7.7 \pm 8.3$ 개월, $4.9 \pm 2.6 \mathrm{~kg}, 56.7 \pm 11.5 \mathrm{~cm}$ 이었다. 입원 시 연령별 체중의 3 백분위수(percentile) 이하에 해당하는 사례는 90례(89.1\%) 였다. 
Table 1. Clinical Characteristics of Patients with Bronchopulmonary Dysplasia in PICU

\begin{tabular}{lccc}
\hline & Total $(\mathrm{n}=101)^{\dagger}$ & Group 1 ( $\mathrm{n}=62)$ & Group 2 (n=39) \\
\hline Age at PICU admission (mon) & $7.7 \pm 8.3$ & $9.3 \pm 9.4$ & $5.1 \pm 5.1$ \\
Corrected age at PICU admission (mon) & $5.7 \pm 9.2$ & $7.8 \pm 10.4$ & $2.3 \pm 5.3$ \\
Body weight at PICU admission (kg) & $4.9 \pm 2.6$ & $5.5 \pm 2.8$ & $3.9 \pm 1.9$ \\
Height at PICU admission (cm) & $56.7 \pm 11.5$ & $59.2 \pm 11.8$ & $52.9 \pm 10.0$ \\
BNP level at PICU admission (pg/mL) & & $1,433.7 \pm 2,233.5$ & $72.9 \pm 139.6$ \\
Interval between NICU care to PICU admission (d) & $120.9 \pm 233.0$ & $152.2 \pm 272.6$ & ROP (14), Inguinal hernia (7), \\
Reason for PICU admission & & Respiratory 56 (90.3\%), Cardiovascular & Heart surgery (6), GI surgery (5), \\
& & $3(4.8 \%)$, Neurology 2 (3.2\%), Gastro- & CNS surgery (5), Other (2)* \\
& & intestinal 1 (1.6\%) & 39 \\
Ventilator care & 90 & 51 & $3.3 \pm 2.4$ \\
PICU stay (d) & $31.7 \pm 68.0$ & $49.6 \pm 82.1$ & $12.6 \pm 16.8$ \\
Total hospital stay (d) & $44.0 \pm 76.1$ & $63.5 \pm 90.9$ & $0(0 \%)$ \\
Mortality & $5(4.9 \%)$ & $5(8.1 \%)$ &
\end{tabular}

*Thoracic duct ligation for chylothorax, hyaluronic acid injection for vocal cord palsy.

${ }^{\dagger}$ Unless otherwise indicated, data are number of episodes of PICU admission.

Abbreviations: BNP, brain natriuretic peptide; NICU, neonatal intensive care unit; PICU, pediatric intensive care unit; ROP, retinopathy of prematurity; GI, gastrointestinal; CNS, central nervous system.

Plus-minus values are mean \pm SD.

신생아중환자실 퇴원 이후 소아중환자실 입원까지의 기간은 평균 $120.9 \pm 233.0$ 일 이었다.

1 군 환자들 중 소아중환자실 입원 당시의 체중이 연령별 체중 의 3 백분위수 이하에 해당하는 사례는 54례(87.1\%) 이었다. 1 군 환자들의 소아중환자실 입원 원인은 대부분 호흡 곤란과 호흡 부 전이 주를 이루었고(90.3\%), 이는 호흡기 감염 또는 기관지폐이 형성증에 동반된 폐동맥 고혈압 악화에 의한 것이었다. 그 외에 는 심부전(4.8\%), 경련(3.2\%), 토혈(1.6\%) 등의 이유로 소아중환 자실에 입원 하였다. 이들 중 호흡기 증상을 주소로 내원한 환자 에 한하여 호흡기바이러스 검사를 시행한 결과, 12 례에서 호흡기 바이러스가 검출되었고, Parainfluenza virus 36례, Respiratory syncytial virus (RSV) 4례, Rhinovirus 2례, Bocavirus 1례 확인 되었다. 2009년 이전에 시행한 검사는 비인두강 검체를 통한 배양 검사로, 나머지는 비인두강 검체를 통한 PCR (polymerase chain reaction) 검사로 검출 되었다. 소아중환자실 입원 기간은 평균 $49.6 \pm 11.8$ 일 이었으며 소아중환자실 입원 기간을 포함한 총 병 원 입원 기간은 평균 $63.5 \pm 90.9$ 일 이었다. 연구기간 중 총 5 례의 사망이 있었고, 이는 총 입원 사례 중 $8.1 \%$ 에 해당한다. 사망 원인 은 주로 환자의 기저질환의 악화 또는 이와 동반된 합병증에 의한 것이었다. 기관지폐이형성증과 동반된 폐동맥고혈압으로 장기간 의 기계환기 이탈 실패로 사망한 경우가 3례가 있었고, 선천성 횡 격막 탈장에 의한 심폐부전의 악화로 인한 사망과 다운증후군 관 련 폐질환의 악화에 따른 호흡부전에 의한 사망이 각각 1 례씩 있 었다. 사망한 환자들 중 3 명은 중증 기관지폐이형성증을, 2 명은 경
증 기관지폐이형성증을 진단 받았었다. 중증 기관지폐이형성증을 진단 받았던 3 명 중 2 명은 재태 연령 30 주 미만, 출생 체중 1,000 $\mathrm{g}$ 미만의 초극소저체중출생아 였고, 이 둘은 신생아중환자실에서 퇴원 시 산소가 필요로 하였다.

2군에 해당하는 환자들은 36례(92.3\%)의 경우 소아중환자실 입원 당시의 체중이 연령별 체중의 3 백분위수 이하에 해당하였 다. 입원 이유에는 미숙아망막증 수술이 14례(35.9\%), 서혜부 탈 장 수술이 7례(17.9\%), 심방중격결손 또는 심실중격결손과 같은 예정된 정규 심장 수술이 6례(15.4\%), 위루관 삽입, 장루 복원 등 의 소화기계 수술이 5례(12.8\%), 뇌실복강단락술 등의 중추신경 계 수술이 5례(12.8\%), 이에 해당하지 않는 기타 수술이 2례 있었 다. 2 군의 환자들 중 소아중환자실 입원 중 사망한 환자는 없었다.

1 군과 2군 두 집단 간 비교 분석 결과, 재태 연령과 신생아중환 자실 퇴원시의 교정연령이 1 군에서 2 군에 비해 높았고, 인공호 흡기 사용 기간, 산소 치료 기간, 신생아중환자실 재원 기간, 또 한 1 군에서 2 군에 비해 의미 있게 길었던 것이 확인되었다(Table 1). 반면 출생 체중, 1 분 및 5 분 Apgar score, 성별, 출산 방법, surfactant 투여 여부, 산모의 나이, 귀가 시 산소 필요 여부 등은 두 집단 사이에 의미 있는 차이를 보이지 않았다(Table 2).

\section{2. 예후 인자 분석}

1 군의 환자들을 대상으로 소아중환자실 재실기간, 총 재원기간 및 사망에 대한 예후 인자 분석 결과, 소아중환자실 입실 당시 체 중 만이 소아중환자실 재실기간 및 총 재원기간과 통계적으로 유 
Table 2. Basic Characteristics of the Study Population

\begin{tabular}{|c|c|c|c|c|}
\hline Parameters & Total $(\mathrm{n}=78)^{*}$ & Group $1(n=41)$ & Group $2(n=37)$ & $P$-value \\
\hline Sex (male:female) & $45: 33$ & $26: 15$ & 19:18 & 0.282 \\
\hline Gestational age (wks) & $29.2 \pm 4.1$ & $30.3 \pm 4.4$ & $28.0 \pm 3.5$ & 0.011 \\
\hline Birth weight (g) & $1,241 \pm 691$ & $1,360 \pm 721$ & $1,110 \pm 640$ & 0.108 \\
\hline Maternal age (y) & $32.4 \pm 4.1$ & $32.4 \pm 4.2$ & $32.3 \pm 4.0$ & 0.965 \\
\hline \multicolumn{5}{|l|}{ Apgar score } \\
\hline $1 \mathrm{~min}$ & $4.0(0-8)(\mathrm{n}=66)$ & $5.1(1-7)(\mathrm{n}=32)$ & $5(0-8)(n=34)$ & 0.952 \\
\hline $5 \min$ & $6.1(1-9)(n=66)$ & $7.8(1-9)(n=32)$ & $7(2-9)(\mathrm{n}=34)$ & 0.902 \\
\hline Delivery & NSVD (18), C/sec (60) & $\operatorname{NSVD}(8), \mathrm{C} / \sec (33)$ & NSVD (10), C/sec (27) & 0.432 \\
\hline Surfactant therapy for RDS & yes (52), no (26) & yes (24), no (17) & yes (28), no (9) & 0.09 \\
\hline Duration of $\mathrm{O}_{2}$ therapy (d) & $95.3 \pm 79.1(\mathrm{n}=71)$ & $124.1 \pm 100.1(\mathrm{n}=34)$ & $68.8 \pm 38.5$ & 0.004 \\
\hline Duration of MV (d) & $57.7 \pm 66.4(\mathrm{n}=71)$ & $78.1 \pm 84.9(\mathrm{n}=34)$ & $38.4 \pm 33.2$ & 0.013 \\
\hline Duration of NICU care (d) & $106.2 \pm 65.1(n=73)$ & $123.9 \pm 81.6(\mathrm{n}=36)$ & $89.0 \pm 37.1$ & 0.024 \\
\hline Corrected age at NICU discharge (wks) & $3.4 \pm 9.5$ & $5.9 \pm 11.7$ & $0.7 \pm 5.3$ & 0.013 \\
\hline \multirow[t]{3}{*}{ BPD severity } & mild (28) & mild (9) & mild (19) & \\
\hline & moderate (27) & moderate (10) & moderate (17) & \\
\hline & severe (23) & severe (22) & severe (1) & \\
\hline Home $\mathrm{O}_{2}$ at discharge & yes (40), no (38) & yes (25), no (16) & yes (15), no (22) & 0.112 \\
\hline
\end{tabular}

Abbreviations: RDS, respiratory distress syndrome; MV, mechanical ventilator; NICU, neonatal intensive care unit; BPD, bronchopulmonary dysplasia; NSVD, normal spontaneous vaginal delivery; C/sec, cesarean section.

*Unless otherwise indicated, data are numbers of patients.

Plus-minus values are mean \pm SD.

의한 상관관계를 보였다. 또한 신생아중환자실에서의 예후 인자와 소아중환자실 재실기간 및 총 재원기간 사이에 유의한 결과는 없 었다. 사망과 관련하여 유의한 상관관계를 보인 인자들은 없었다 (Table 3). 이들을 각각 기관지폐이형성증의 중증도, 재태 연령, 출 생 체중 별로 세분화 하였을 때 소아 중환자실 재실기간, 총 재원 기간, 기계환기 필요 여부에 대한 통계적 유의성과 경향성을 찾을 수 없었다(Table 4).

\section{고찰}

만성 폐질환이란 신생아기의 호흡기 질환에 의한 다양한 폐질 환을 통칭 하는 말로서 이 중 기관지폐이형성증은 영아기 만성폐 질환을 일으키는 가장 흔한 원인 질환으로 알려져 있다. 기관지폐 이형성증은 1967년, 신생아 호흡곤란 증후군을 가진 미숙아가 기 계환기와 고농도의 산소치료에 노출됨에 따라 발생하는 만성 호 흡기 질환으로 처음 소개 되었다 ${ }^{4}$. 미숙아에 대한 산전 스테로이 드와 surfactant 투여 및 호흡기, 감염, 영양 보충과 같은 보존적 치 료가 발전함에 따라 더 작은 주수에 출생한 환자들의 생존률이 향상 되었고, Jobe 등근 은들 미숙아들이 최소한의 기계환기 보 조와 저농도 산소치료를 받았음에도 불구하고 이들에게서도 기
Table 3. Correlation Between Basic Characteristics and Prognostic Outcomes

\begin{tabular}{|c|c|c|c|c|}
\hline & \multicolumn{2}{|c|}{ PICU Stay } & \multicolumn{2}{|c|}{ Hospital Stay } \\
\hline & $R^{2}$ & $P$-value & $R^{2}$ & $P$-value \\
\hline Age at PICU admission & 0.611 & 0.182 & 0.619 & 0.126 \\
\hline Corrected age at PICU admission & 0.611 & 0.208 & 0.619 & 0.175 \\
\hline Body weight at PICU admission & 0.611 & 0.015 & 0.619 & 0.025 \\
\hline Height at PICU admission & 0.611 & 0.057 & 0.619 & 0.054 \\
\hline BNP level at PICU admission $(\mathrm{pg} / \mathrm{mL})$ & 0.611 & 0.539 & 0.619 & 0.405 \\
\hline $\begin{array}{l}\text { Interval between NICU care to PICU } \\
\text { admission (d) }\end{array}$ & 0.611 & 0.213 & 0.619 & 0.184 \\
\hline Gestational age & 0.611 & 0.586 & 0.619 & 0.248 \\
\hline Birth weight & 0.611 & 0.779 & 0.619 & 0.284 \\
\hline \multicolumn{5}{|l|}{ Apgar score } \\
\hline $1 \mathrm{~min}$ & 0.611 & 0.311 & 0.619 & 0.762 \\
\hline $5 \mathrm{~min}$ & 0.611 & 0.347 & 0.619 & 0.514 \\
\hline Duration of $\mathrm{O}_{2}$ therapy in $\mathrm{NICU}(\mathrm{d})$ & 0.611 & 0.794 & 0.619 & 0.620 \\
\hline Duration of MV in NICU (d) & 0.611 & 0.783 & 0.619 & 0.654 \\
\hline Duration of NICU care (d) & 0.611 & 0.552 & 0.619 & 0.440 \\
\hline Corrected age at NICU discharge & 0.611 & 0.941 & 0.619 & 0.759 \\
\hline Home $\mathrm{O}_{2}$ at NICU discharge & & 0.277 & & 0.282 \\
\hline
\end{tabular}

Abbreviations: PICU, pediatric intensive care unit; BNP, brain natriuretic peptide; NICU, neonatal intensive care unit; MV, mechanical ventilator. 
Table 4. Comparison of Prognostic Factors within Subgroups of Group 1

\begin{tabular}{|c|c|c|c|c|c|c|c|c|c|c|c|c|}
\hline & \multicolumn{4}{|c|}{ BPD severity } & \multicolumn{4}{|c|}{ Gestational age (wks) } & \multicolumn{4}{|c|}{ Birth weight (g) } \\
\hline & $\begin{array}{l}\text { Mild } \\
(n=15)\end{array}$ & $\begin{array}{c}\text { Moderate } \\
(\mathrm{n}=11)\end{array}$ & $\begin{array}{l}\text { Severe } \\
(\mathrm{n}=36)\end{array}$ & $\begin{array}{c}P \text { - } \\
\text { value }\end{array}$ & $\begin{array}{c}<28 \\
(n=19)\end{array}$ & $\begin{array}{l}28-<32 \\
(n=18)\end{array}$ & $\begin{array}{c}\geq 32 \\
(n=25)\end{array}$ & $\begin{array}{c}P \text { - } \\
\text { value }\end{array}$ & $\begin{array}{l}<1,000 \\
(n=22)\end{array}$ & $\begin{array}{c}1,000-1,499 \\
(n=9)\end{array}$ & $\begin{array}{l}\geq 1,500 \\
(n=31)\end{array}$ & $\begin{array}{c}P \text { - } \\
\text { value }\end{array}$ \\
\hline PICU stay* & $45.7 \pm 82.8$ & $18.6 \pm 19.8$ & $60.7 \pm 91.9$ & 0.328 & $47.6 \pm 60.6$ & $40.2 \pm 98.4$ & $50.8 \pm 85.9$ & 0.786 & $64.3 \pm 99.4$ & $51.2 \pm 103.9$ & $38.6 \pm 60.1$ & 0.539 \\
\hline Hospital stay* & $66.2 \pm 84.2$ & $29.6 \pm 23.8$ & $72.9 \pm 104.5$ & 0.389 & $56.5 \pm 56.9$ & $51.2 \pm 104.7$ & $78.4 \pm 102.6$ & 0.587 & $75.2 \pm 101.5$ & $61.0 \pm 100.8$ & $55.0 \pm 81.5$ & 0.713 \\
\hline $\begin{array}{l}\text { Ventilator } \\
\text { requirement }{ }^{\dagger}\end{array}$ & $\begin{array}{c}13 / 15 \\
(86.7 \%)\end{array}$ & $\begin{array}{c}8 / 11 \\
(72.7 \%)\end{array}$ & $\begin{array}{c}30 / 36 \\
(83.3 \%)\end{array}$ & 0.634 & $\begin{array}{c}15 / 19 \\
(78.9 \%)\end{array}$ & $\begin{array}{c}12 / 18 \\
(66.7 \%)\end{array}$ & $\begin{array}{c}24 / 25 \\
(96.0 \%)\end{array}$ & 0.041 & $\begin{array}{c}16 / 22 \\
(72.7 \%)\end{array}$ & $\begin{array}{c}8 / 9 \\
(88.9 \%)\end{array}$ & $\begin{array}{c}27 / 31 \\
(87.1 \%)\end{array}$ & 0.343 \\
\hline
\end{tabular}

*One-way analysis of variance.

${ }^{\dagger}$ Pearson chi-square test.

Abbreviations: BPD, bronchopulmonary dysplasia; PICU, pediatric intensive care unit.

Plus-minus values are mean \pm SD.

관지폐이형성증이 발현함을 관찰하였다. 1999년, 이러한 질환 군 에 대해 이전 Northway 등에 의해 소개되었던 것과는 달리, 미 숙아로 출생하여 폐포화(alveolarization)가 되지 않은 상태의 환 자들에서 출생 후에 산소 치료, 기계 환기 치료, 감염 등에 의한 cytokine 노출, 그 외에 스테로이드 치료, 영양 상태와 같은 다양 한 원인에 의해 폐 발달 과정이 방해됨에 따라 발생하게 되는 새로 운 병태 생리학적 개념의 기관지폐이형성증이 정의되었다도. 현재 기관지폐이형성증에 대하여는 2001년 Jobe와 Bancalari가 제시 한 진단 기준이 활용되고 있는데 이에 의하면, 최소한 출생 28 일 이후까지 산소 공급일 필요한 경우를 기관지폐이형성증으로 정의 하였고, 교정 주수가 만삭에 이르렀을 때 필요한 호흡 보조 정도에 따라 중증도를 결정한다 ${ }^{3)}$.

매해 미국에서는 총 출생의 $1.5 \%$ 인 60,000 명의 극소저체중아 가 태어나고 이중 $20 \%$ 에서 기관지폐이형성증이 발생하는 것으로 보고되고 있으며 ${ }^{6)}$, 국내에서도 총 출생아 중 $1.6 \%$, 극소저체중아 의 20-25\%에서 기관지폐이형성증이 진단 되는 것으로 보고된 바 있다 ${ }^{78)}$. 이는 이전 보고와 비교해 볼 때 기관지페이형성증 환자의 발생이 꾸준히 증가되고 있으며 향상된 미숙아 치료 및 관리에 따 라 이들의 유병률 또한 증가되고 있는 추세이다'. 최근 이들 환자 들에 대한 중장기 임상 경과에 대한 연구가 발표되었는데, 그에 따 르면 생후 1 개월경 이들의 기도의 전도도가 감소하고, 기도 저항 은 증가해 있는데 2-3세경 정상화 되는 것이 확인되었다 ${ }^{10,11}$. 또한 최대호기유량과 노력성 폐활량이 유아기에 이르러서도 정상 수치 에 비해 감소한 것이 확인됨에 따라 기관지폐이형성증을 않지 않 은 소아에 비해 잦은 호흡기 증상의 발현과 감염의 위험이 있으며, 기관지 확장제와 흡입 스테로이드와 같은 천식치료제가 더 빈번히 처방되는 결과에 이르렀다 ${ }^{10,12-15)}$.

이에 기관지폐이형성증 환자들의 신생아중환자실 퇴원 후에 재 입원하게 되는 빈도, 이와 관련된 위험인자들에 대한 연구와 영아 기부터 청소년기, 나아가 성인기까지의 폐기능 검사를 추적하여 중·장기적 경과에 대한 연구가 발표 되었다 ${ }^{1,2,12,16,17)}$.
미숙아 자체는 기관지폐이형성증의 유무와 상관없이 폐 손상 및 장기적인 폐 기능장애의 주된 위험 요소로 알려져 있다. 그러 나 출생 당시 산모의 특성, 환자의 출생 정보, surfactant 치료, 산 소치료 유지 기간, 기관지폐이형성증의 중증도와 같은 신생아중 환자실에서의 인자는 이후의 중장기적 임상 경과 및 예후 예측에 유용하지 않음이 보고된 바 있다 ${ }^{15,18)}$. 반면에 저체중출생아로 신 생아중환자실에서 퇴원 후 재입원하게 된 환자를 대상으로 한 국 내 연구 결과, 출생체중, 기관지폐형성 유무, 신생아중환자실에서 의 기계환기 치료 기간과 입원 기간은 신생아중환자실 퇴원 이후 의 입원 빈도 증가와 관련이 있음이 발표되었다 ${ }^{19)}$. 본 연구 결과 재 태 연령, 출생 체중, 분만 방법, surfactant 투여 여부 등의 주산기 관련 인자들, 그리고 총 산소 치료 또는 기계 환기 치료 기간, 입원 기간, 신생아중환자실 퇴원시 교정연령, 기관지폐이형성증의 중증 도, 귀가 시 산소 필요 여부 등의 신생아중환자실 치료 관련 인자 들은 모두 소아중환자실에서의 입원 기간 및 사망 여부와 유의한 관련성을 보이지 않았다. 급성질환 악화에 따른 소아중환자실 입 원 치료가 필요하였던 1 군의 경우 수술 후 관리를 위해 소아중환 자실에 입원한 2 군과의 비교 분석 결과 기관지폐이형성증의 중증 도는 유의한 차이를 보이지 않았지만, 신생아중환자실에서의 산소 투여 기간, 기계 환기 적용 기간, 총 입원 기간에서 유의하게 차이 를 보였다. 앞선 보고에서 기관지폐이형성증이 동반된 환자의 절 반에 가까운 수가 생후 1 년 이내에 하기도 질환과 동반된 급성 호 흡 곤란을 주소로 재입원한 것이 확인되었고, 특히 입원의 빈도가 1 세 이전에 집중되었다가 생후 2-3세경부터 감소하는 것을 알 수 있었다 ${ }^{14,18,20-22)}$. 본 연구에서도 대부분의 환자가 소아중환자실 입 원 당시의 나이가 영아기에 해당 되었고, 많은 수의 환자가 호흡기 증상을 주소로 소아중환자실 외에도 일반 병동으로 반복입원 치 료를 필요로 하였으며 성장과 함께 그 빈도가 감소함을 알 수 있 었다. 이는 환자의 성장에 따른 이후의 기도의 성장과 새로운 폐포 의 발달에 의해 어느 정도 설명될 수 있는 병태 생리학적 현상이라 할 수 있겠으며 이와 더불어 1999년, 기관지폐이형성증을 진단 받 
은 24 명의 영아를 대상으로 생후 2년 동안 정기적인 폐기능 검사 를 추적한 연구에서 기존에 악화되어 있던 폐기능이 생후 1년간 호전을 보이다가 2세경 정상 범위에 도달함을 보고한 연구에 의해 또한 지지될 수 있을 것이다 ${ }^{10,12)}$. 반면, 생후 5 세경 까지는 어느 정 도의 폐기능 검사 상 이상 소견이 지속된다는 다른 결과의 보고들 도 있어 ${ }^{13)}$, 폐기능 검사뿐만 아니라 계절에 따른 유행하는 바이러 스의 차이, 동반 질환의 유무, 흡연에 대한 노출 유무, 형제 또는 육 아시설 방문 여부 등의 여러 다양한 요인에 의한 영아기의 잦은 입 원과 높은 중증도를 설명할 수 있을 것으로 보인다.

앞서 언급한 기관지폐이형성증 환자들의 폐기능 이상은 이들이 바이러스에 의한 하기도 감염에 대한 저항력이 부족함에 따라 이 로 인한 재입원 반복됨을 설명할 수 있다 ${ }^{1,19,21,23)}$. 본 연구에서도 대 부분의 환자가 호흡기 감염에 의한 기저질환 악화를 주소로 소아 중환자실에 입원하게 되었다. RSV에 의한 감염이 기관지폐이형성 증 환자들의 주된 재입원 원인인 것은 잘 알려져 있으며 ${ }^{21,23-26)}$, 본 연구에서는 Paravinfluenza virus 3와 함께 RSV가 일부 호흡기 감염의 원인으로 확인되었다. 이와 같이 호흡기 바이러스 감염에 의한 재입원이 영아기에 집중 되어 있다는 점에서, 이 시기의 호흡 기 바이러스 감염에 대한 적극적인 예방과 주의 깊은 경과 관찰 및 적절한 시기의 즉각적인 치료가 매우 중요함을 시사한다. 특히 기 관지폐이형성증 환자들에게 치명적일 수 있는 바이러스에 대하여 는 Palivizuma 투여와 같은 적극적인 예방이 필요할 것으로 보인 다 ${ }^{24,27,28)}$.

본 연구에서 급성 질환의 악화로 소아중환자실에 입원한 1 군 의 환자들 중, 입원 당시의 체중이 작을수록 소아중환자실 입원 기간과 총 병원 입원 기간이 긴 것이 선형회기분석에서 확인되었 다. 또한 급성 질환의 악화로 입원한 소아중환자실에 입원한 사례 중 $87 \%$ 의 체중이 연령대비 3 백분위 미만이었던 것은 기관지폐 이형성증 환자들의 중장기적 예후에는 적절한 성장과 발달이 중 요함을 의미한다. 이에 신생아중환자실에서뿐만 아니라 외래 추 적 관찰 중에도 기관지폐이형성증 환자가 적절한 성장을 할 수 있 도록 적극적인 영양 평가와 개입이 필요할 것으로 판단된다. 성 인 기관지폐이형성증 환자를 대상으로 한 연구에서 BNP (brain natriuretic peptide)의 상승이 폐동맥고혈압과 사망의 예측 인 자로 의미가 있음이 발표되었으나 ${ }^{29)}$, 본 연구에서는 입원 당시의 $\mathrm{BNP}$ 수치가 환자들의 소아중환자실 입원 기간이나 사망 관련예 후를 반영하지 못했다. 그 외에 소아중환자실 입원 당시 동맥혈가 스분석 상의 수소 이온 농도, 산소 분압, 이산화탄소 분압, 젖산 농 도 역시 입원 기간 중 예후 예측에 유의한 결과를 보이지 않았다. 따라서, 앞으로 이들 환자들의 소아중환자실 입원 관련 재원 기간 및 사망에 대한 예후 인자에 대해서는 조금 더 대규모의 많은 연 구들이 필요할 것으로 생각된다.

본 연구의 제한점으로는 의무기록 고찰을 기반으로 한 후향적
연구였다는 점과 연구의 대상 환자 수가 많지 않았던 점을 들 수 있다. 많은 연구에서 기관지폐이형성증 환자의 장기적 경과의 지 표로 활용되고 있는 폐기능 검사의 결과를 확보하지 못한 것 역시 제한점이다. 또한 출생 당시의 재태연령, 출생체중 등을 기준으로 한 case-matched 대조군을 설정하지 못한 점을 제한점으로 들 수 있다. 그러나 이러한 제한점에도 불구하고 기관지폐이형성증을 가진 환자들 중 소아중환자실에서의 입원 치료를 필요로 하는 중 증 환자들을 대상으로 이들의 임상경과 및 급성질환 악화와 관련 한 예후 인자들에 대한 분석 및 고찰을 시행 하였다는 점에서 그 의의가 있다고 할 수 있겠다.

본 연구 결과, 소아중환자실에 입원한 기관지폐이형성증 환자들 은 신생아중환자실에서 인공호흡기 치료 및 산소 치료 기간이 길 었던 경향이 있었고, 이들의 주된 입원 이유는 호흡 곤란과 기계적 보조를 필요로 하는 호흡 부전이었다. 일부의 환자에서는 호흡기 바이러스 감염이 이를 일으킬 수 있는 인자로 확인되었고, 영아기 에 그 위험성이 더 큰 것으로 나타났다. 앞으로 이 연구를 토대로 좀 더 많은 수의 환자들을 대상으로 한 체계적인 분석 연구를 통 해 이들 기관지폐이형성증을 가진 환자들의 상태 악화 및 장기적 예후 인자들에 대해 알아보고, 신생아중환자실에서의 미숙아 관 리에 있어 이후 폐손상을 최소화 하고 기능 회복에 도움이 될 수 있는 치료 방침의 마련 및 악화 요인 선별을 통해 기관지폐이형성 증을 가진 영아들에 대한 적극적 예방, 관리, 치료 및 임상 경과의 향상에 도움이 될 수 있도록 해야겠다.

\section{REFERENCES}

1) Eber E, Zach MS. Long term sequelae of bronchopulmonary dysplasia (chronic lung disease of infancy). Thorax 2001; 56:317-23.

2) Northway WH, Jr., Moss RB, Carlisle KB, Parker BR, Popp RL, Pitlick PT, et al. Late pulmonary sequelae of bronchopulmonary dysplasia. N Engl J Med 1990;323:1793-9.

3) Jobe AH, Bancalari E. Bronchopulmonary dysplasia. Am J Respir Crit Care Med 2001;163:1723-9.

4) Northway WH, Jr., Rosan RC, Porter DY. Pulmonary disease following respirator therapy of hyaline-membrane disease. Bronchopulmonary dysplasia. N Engl J Med 1967;276:357-68.

5) Jobe AJ. The new BPD: an arrest of lung development. Pediatr Res 1999;46:641-3.

6) Lemons JA, Bauer CR, Oh W, Korones SB, Papile LA, Stoll BJ, et al. Very low birth weight outcomes of the National Institute of Child Health and Human Development Neonatal Research Network, January 1995 through December 1996. Pediatrics 2001;107:E1. 
7) Sung KH, Kim MH, Kim ER, Shim JW, Lee JJ, Im JW, et al. Epidemiology of bronchopulmonary dysplasia in Korea: multi-center study. Korean J Perinatol 2009;20:225-33.

8) Choi CW, Kim BI, Kim EK, Song ES, Lee JJ. Incidence of bronchopulmonary dysplasia in Korea. J Korean Med Sci 2012;27: 914-21.

9) Jensen EA, Schmidt B. Epidemiology of bronchopulmonary dysplasia. Birth Defects Res A Clin Mol Teratol 2014;100:14557.

10) Baraldi E, Filippone M, Trevisanuto D, Zanardo V, Zacchello F. Pulmonary function until two years of life in infants with bronchopulmonary dysplasia. Am J Respir Crit Care Med 1997;155:149-55.

11) Gerhardt T, Hehre D, Feller R, Reifenberg L, Bancalari E. Serial determination of pulmonary function in infants with chronic lung disease. J Pediatr 1987;110:448-56.

12) Hayes D, Jr., Meadows JT, Jr., Murphy BS, Feola DJ, Shook LA, Ballard HO. Pulmonary function outcomes in bronchopulmonary dysplasia through childhood and into adulthood: implications for primary care. Prim Care Respir J 2011;20:12833.

13) Islam JY, Keller RL, Aschner JL, Hartert TV, Moore PE. Understanding the short- and long-term respiratory outcomes of prematurity and bronchopulmonary dysplasia. Am J Respir Crit Care Med 2015;192:134-56.

14) Bhandari A, Panitch HB. Pulmonary outcomes in bronchopulmonary dysplasia. Semin Perinatol 2006;30:219-26.

15) Vom Hove M, Prenzel F, Uhlig HH, Robel-Tillig E. Pulmonary outcome in former preterm, very low birth weight children with bronchopulmonary dysplasia: a case-control follow-up at school age. J Pediatr 2014;164:40-5. e4.

16) Landry JS, Chan T, Lands L, Menzies D. Long-term impact of bronchopulmonary dysplasia on pulmonary function. Can Respir J 2011;18:265-70.

17) Saarenpaa HK, Tikanmaki M, Sipola-Leppanen M, Hovi $P$, Wehkalampi K, Siltanen M, et al. Lung function in very low birth weight adults. Pediatrics 2015;136:642-50.

18) Furman L, Baley J, Borawski-Clark E, Aucott S, Hack M. Hospitalization as a measure of morbidity among very low birth weight infants with chronic lung disease. J Pediatr 1996;128: 447-52.
19) Choi KD, Chae YS, Lee K. Rehospitalization of low-birthweight infants who were discharged from NICU. Korean J Pediatr 1999;42:484-90.

20) Cunningham CK, McMillan JA, Gross SJ. Rehospitalization for respiratory illness in infants of less than 32 weeks' gestation. Pediatrics 1991;88:527-32.

21) Greenough A, Alexander J, Burgess S, Bytham J, Chetcuti PA, Hagan J, et al. Health care utilisation of prematurely born, preschool children related to hospitalisation for RSV infection. Arch Dis Child 2004;89:673-8.

22) Lamarche-Vadel A, Blondel B, Truffer $P$, Burguet $A$, Cambonie $\mathrm{G}$, Selton D, et al. Re-hospitalization in infants younger than 29 weeks' gestation in the EPIPAGE cohort. Acta Paediatr 2004; 93:1340-5.

23) Kinsella JP, Greenough A, Abman SH. Bronchopulmonary dysplasia. Lancet 2006;367:1421-31.

24) Lee EA, Jeong JH, Yu ST, Lee CW, Yoon HS, Park DS, et al. Incidence and risk factors of rehospitalization with respiratory syncytial virus infection in premature infants. Korean J Pediatr 2004;47:510-4.

25) Kristensen K, Dahm T, Frederiksen PS, Ibsen J, Iyore E, Jensen AM, et al. Epidemiology of respiratory syncytial virus infection requiring hospitalization in East Denmark. Pediatr Infect Dis J 1998;17:996-1000.

26) Nachman SA, Navaie-Waliser M, Qureshi MZ. Rehospitalization with respiratory syncytial virus after neonatal intensive care unit discharge: a 3-year follow-up. Pediatrics 1997;100: E8.

27) Allen J, Zwerdling R, Ehrenkranz R, Gaultier C, Geggel R, Greenough A, et al. Statement on the care of the child with chronic lung disease of infancy and childhood. Am J Respir Crit Care Med 2003;168:356-96.

28) Park SK, Jung YJ, Yoo HS, Ahn SY, Seo HJ, Choi SH, et al. Effect of palivizumab prophylaxis on readmission due to respiratory syncytial virus in very low birth weight infants. Korean J Pediatr 2010;53:358-63.

29) Leuchte HH, Baumgartner RA, Nounou ME, Vogeser M, Neurohr C, Trautnitz $\mathrm{M}$, et al. Brain natriuretic peptide is a prognostic parameter in chronic lung disease. Am J Respir Crit Care Med 2006;173:744-50. 